FILOLOGIJA 74, Zagreb 2020.

UDK 811.163.42'35"1941/1945"

DOI https://dx.doi.org/10.21857/y26kec47j9

Izvorni znanstveni članak

Rukopis primljen 20. IV. 2020.

Prihvaćen za tisak 22. V. 2020.

\title{
Tamara Rešetar
}

Osnovna škola Cestica

Dravska ulica 2, HR-42208 Cestica

tamara.resetar@skole.hr

Borana Morić-Mohorovičić

Odsjek za kroatistiku

Filozofski fakultet

Sveučilište u Rijeci

Sveučilišna avenija 4, HR-51000 Rijeka

bmoric@ffri.hr

\section{PRAVOPIS U NEZAVISNOJ DRŽAVI HRVATSKOJ (na primjeru novina Hrvatsko jedinstvo)*}

\begin{abstract}
$\mathrm{U}$ radu se razmatra pravopisna norma u tjedniku Hrvatsko jedinstvo $\mathrm{u}$ vrijeme Nezavisne Države Hrvatske. Kao normativne se značajke nove, morfonološke pravopisne norme uzimaju značajke koje se navode $\mathrm{u}$ Ministarskoj naredbi o hrvatskom pravopisu (1941), Zakonskoj odredbi o hrvatskom jeziku, o njegovoj čistoći i o pravopisu (1941) te Provedbenoj naredbi k zakonskoj odredbi o hrvatskom jeziku, o njegovoj čistoći i pravopisu (1942), a pobliže pojašnjavaju u Klaićevu Korienskom pisanju (1942) te Cipra-Klaićevu Hrvatskom pravopisu (1944). Analizom će biti utvrđeno i kada su novine u potpunosti prešle na morfonološki pravopis.
\end{abstract}

Dolaskom ustaške vlasti u Varaždin, na čelu s Matom Frkovićem ${ }^{1}$ i Ljudevitom Banom, ${ }^{2}$ 11. travnja 1941. godine, ${ }^{3}$ gase se Varaždinske novo-

* Ovaj je rad financiralo Sveučilište u Rijeci projektima uniri-human-18-13 1140 i uniri-human-18-285.

1 Mate Frković, član Glavnog ustaškog stana, bio je ustaški povjerenik za bivšu Županiju varaždinsku. Usp. Huzjan 2012.

2 Ljudevit Ban bio je Povjerenik općine grada Varaždina od 11. travnja do 30. travnja 1941. godine, nakon čega tu dužnost preuzima Vjekoslav (Slavko) Medvedović. Usp. Huzjan 2012.

3 Podsjetimo da je Nezavisnu Državu Hrvatsku preko radija proglasio vođa domovinske ustaške skupine Slavko Kvaternik (1878-1947) tek dan ranije: 10. travnja 
sti, ${ }^{4}$ a službeno glasilo ustaške vlasti u Velikoj župi Zagorje ${ }^{5}$ i u Varaždinu postaje Hrvatsko jedinstvo. ${ }^{6}$ Ustaški je režim utjecao na sadržaj i retoriku novina, pa je tako već krajem travnja 1941. godine novoosnovani Hrvatski ustaški stožer, koji je bio zadužen za izdavanje oglasa i propisa u Hrvatskom jedinstou, počeo prenositi službene rasne odredbe o Zidovima, primjerice zabrana zapošljavanja žena u nearijskim kućanstvima, predaja židovske imovine, nošenje židovskih oznaka itd. (Huzjan 2012:371). Osim u sadržaju totalitarni se režim dade iščitati i u direktivnom modelu jezične politike, ${ }^{7}$ koji je izgrađivan i provođen brojnim zakonskim odredbama i provedbenim naredbama koje je mahom donosio Hrvatski državni ured za $j e z i k,{ }^{8}$ ali i sam Ante Pavelić. Takvim se dokumentima regulirala upotreba hrvatskoga jezika, pravopisa i pisma u javnoj komunikaciji. Novoosnovana je država jezična, osobito pravopisna pitanja smatrala upravo strateški

1941. godine. O osnutku Nezavisne Države Hrvatske usp. npr. Jelić-Butić 1978; Jonjić 2011.

4 Varaždinske novosti izlazile su od 12. prosinca 1929. do 27. ožujka 1941. godine. List je pokrenuo Bogdan Svoboda, koji ga je i tiskao u svojoj tiskari.

5 Zakonska odredba o velikim župama donesena je 10. lipnja 1941. godine. Njome je utvrđen novi upravno-teritorijalni ustroj na području Nezavisne Države Hrvatske. Do kolovoza 1941. uspostavljene su 22 župe, a na čelu se svih velikih župa nalazio župan. Župe su se dalje dijelile na kotare, kotarske ispostave i općine. Na području današnje sjeverozapadne Hrvatske formirana je Velika župa Zagorje s gradom Varaždinom kao upravnim središtem. Usp. npr. Jelić-Butić:1978; Bućin 2001; Huzjan 2012.

6 Tjednik Hrvatsko jedinstvo izlazio je od 16. listopada 1937. do 17. ožujka 1945. godine. Nakon proglašenja Nezavisne Države Hrvatske list u početku mijenja podnaslov u Glasilo Velike župe Zagorje. Od travnja do rujna 1942. list nosi podnaslov Ustaško glasilo za Veliku župu Zagorje, a od rujna 1942. do siječnja 1944. podnaslov je Glasilo za Veliku župu Zagorje. Od siječnja 1944. Hrvatsko jedinstvo postaje Tjednik za politiku, prosvjetu, družtvovna i gospodarska pitanja.

7 Za razliku od liberalnoga modela jezične politike direktivni model jezične politike »sadržava visok stupanj prisutnosti institucija u provođenju te politike i visoku i eksplicitnu obavezu pridržavanja pravila u javnoj komunikaciji i u svim oblicima primjene tog modela« (Škiljan 1988:57). Iako se direktivni model jezične politike najčešće vezuje za totalitarne režime, valja napomenuti da ga može prakticirati i demokratsko društvo, primjerice francuska jezična politika. O ovoj temi usp. npr. Škiljan 1988; Samardžija 2008.

8 Hrvatski državni ured za jezik (u daljnjem tekstu: HDUJ) osnovan je Zakonskom odredbom o osnivanju Hrvatskoga državnoga ureda za jezik 28. travnja 1941. Ujesen 1942. preimenovan je u Ured za hrvatski jezik. Njegovo je djelovanje kao strukovnoga tijela državne uprave precizno određeno Provedbenom naredbom $k$ zakonskoj odredbi o osnivanju Hrvatskoga državnog ureda za jezik 12. srpnja 1941. Tako je HDUJ bio ovlašten za davanje jezičnih savjeta, pregled svih rukopisa prije objavljivanja, jezičnu promičbu te rad na novom hrvatskom pravopisu. O toj temi usp. npr. Samardžija 1993; Samardžija 2008; Samardžija 2018. 
važnima (Badurina 2018:159). U želji da raskinu dominantan fonološki tip pravopisa koji se »ustrajno gradi /.../ od devedesetih godina 19. stoljeća« (Badurina 2018:157) ${ }^{9}$ te uspostave pretežito morfonološki tip pravopisa, ustaška vlast donosi Ministarsku naredbu o hrvatskom pravopisu (23. lipnja 1941. godine), ${ }^{10}$ a potom i Zakonsku odredbu o hrvatskom jeziku, o njegovoj čistoći i o pravopisu (14. kolovoza 1941. godine), ${ }^{11}$ kojom je zabranjen bilo kakav drugi pravopis osim korienskoga, tj. morfonološkoga. ${ }^{12}$ Rezultat je takve zakonodavne jezične politike "privremeni pravopisni priručnik" (Samardžija 2008:56) Koriensko pisanje Adolfa Bratoljuba Klaića $\left({ }^{1} 1942,{ }^{2} 1942\right)$. Iako je riječ o nepotpunom i nabrzinu sastavljenom pravopisnom izdanju (Badurina 2018:160), ${ }^{13}$ ova je knjiga snažno utjecala na tiskovine u vrijeme Nezavisne Države Hrvatske. ${ }^{14}$ Naime, od objave Zakonske odredbe »mnogi su, iz uvjerenja ili iz straha da, ne daj Bože, ne zakasne, žurno napustili 'zvučni pravopis' i počeli pisati 'korienskim' « (Samardžija 2008:47). U tom su razdoblju mnoge novine žurno prelazile na novi, morfonološki pravopis. ${ }^{15} \mathrm{~S}$ obzirom na to da takvu pisanju nisu bili vješti, mnogi su novinari, po osjećaju i vlastitom viđenju onoga što je za njih predstavljao morfonološki pravopis, zapisivali pogrešna individualna rješenja. ${ }^{16}$

9 Hrvatski pravopis Ivana Broza, objavljen u dvama izdanjima u zadnjem desetljeću 19. stoljeća (1892. i 1893), označio je početak stvaranja današnje fonološko-morfonološke pravopisne norme. Takav, dominantno fonološki pravopisni priručnik označio je pobjedu (pravopisne koncepcije) škole hrvatskih vukovaca. Zahvaljujući djelatnosti Dragutina Boranića, »Brozove su se pravopisne zasade« (Badurina 2018:157) protegnule kroz cijelu prvu polovicu 20. stoljeća, uz prekid od 1941. do 1945. u vrijeme Nezavisne Države Hrvatske. O toj temi usp. npr. Brozović 1985; Badurina 2010; Samardžija 2014; Badurina 2015; Pranjković 2015; Badurina 2018.

10 U daljnjem tekstu: Ministarska naredba.

11 U daljnjem tekstu: Zakonska odredba.

12 O društveno-političkom kontekstu u kojem su dokumenti doneseni te o odredbama koje se njima donose usp. Samardžija 2008.

13 Cjelovit je Hrvatski pravopis autora Franje Cipre i Adolfa Bratoljuba Klaića objavljen godine 1944. godine, u suton djelovanja Nezavisne Države Hrvatske.

14 O tome koliko je ovakav priručnik bio potreban, svjedoči i sam autor koji u pravopis uvrštava popis riječi »koje treba prema provedbenoj naredbi Ministarstva nastave pisati drugačije, nego su se do sada pisale, te iznimke i rieči, kod kojih bi uslied krive analogije mogla nastati sumnja o tome kako se pišu « (Klaić 1942:64).

15 »Narodne novine na korijenski su pravopis prešle još 14 . kolovoza 1941. /.../. Sarajevski novi list na novi je pravopis /.../ prešao 7. srpnja 1942. /.../ Osječki hrvatski list na korijenski je pravopis prešao dva mjeseca prije isteka prijelaznoga razdoblja, tj. 1. studenoga 1942.« (Samardžija 2008:56).

16 Usp. npr. »Vrlo težak pravopisni nesklad javio se u ono nekoliko dana, kad su neke naše novine - krivo razumjevši zakon od 14. kolovoza - odmah počele pisati korijenskim' pravopisom. Tada smo mogli čitati ovakve oblike: unižten, ožtećen, družstvo, pjestnik, glastnik, zapovjednikčtvo, privjezka, prisudstvo, uzkrsnuće, sre- 
Prema tome, na novinarima je bio zahtjevan zadatak: širenje ustaške propagande na čistom hrvatskom jeziku ${ }^{17}$ zapisanom novim pravopisom pod strogom kontrolom režima. ${ }^{18}$

Cilj je rada utvrditi tip pravopisne norme koji je bio dominantan u $\mathrm{Hr}$ vatskom jedinstvu. Istraživanjem je obuhvaćen 41 broj novina, od 26. travnja 1941. do 3. ožujka 1945. Utvrđeno je da je Hrvatsko jedinstvo na novi morfonološki pravopis počelo prelaziti u travnju 1942. godine. S obzirom na to u sintezi rezultata neće biti prikazani rezultati ranijih analiziranih brojeva. U početku je novim pravopisom bilo zapisano tek nekoliko leksema. ${ }^{19}$ Sustavniji su zapisi na morfonološkom pravopisu zabilježeni u kasno ljeto iste godine. Dana 10. rujna 1942. godine novine su u potpunosti prešle na novi pravopis. ${ }^{20}$ To je broj u kojem glasilo mijenja podnaslov u Glasilo za Veliku župu Zagorje ${ }^{21}$ te mijenja numeraciju (godište I, broj 1). Držimo da su ustaške vlasti na taj način obilježile prelazak na morfonološki pravopis. Ustaška je vlast morfonološku pravopisnu normu nastojala kodificirati ponajprije Klaićevim Korienskim pisanjem (1942) te Cipra-Klaićevim Hrvatskim pravopisom (1944), ali i Ministarskom naredbom (1941), Zakonskom odredbom (1941) te Provedbenom naredbom (1942). Kao normativne se značajke nove pravopisne norme uzimaju značajke koje se navode u spomenutim zakonskim odredbama i naredbama, a pobliže pojašnjavaju u kasnijim pravopisnim priručnicima Nezavisne Države Hrvatske.

dičte, mosga, siromačtvo i t. d. /.../« (Krstić 1941:12, prema Samardžija 2008:243).

Zbog takve »nevjerojatne ali shvatljive pravopisne zbrke« (Samardžija 1993:14) donesena je Provedbena naredba k zakonskoj odredbi o hrvatskom jeziku, o njegovoj čistoći i pravopisu (27. lipnja 1942. godine) (u daljnjem tekstu: Provedbena naredba) kojom se određuje da je period do 1. siječnja 1943. prijelazno razdoblje, nakon čega se beziznimno mora primjenjivati nova pravopisna norma.

17 O jezičnom purizmu u vrijeme Nezavisne Države Hrvatske usp. npr. Samardžija 1993; Samardžija 2002; Samardžija 2004; Rišner 2006; Samardžija 2008, Baraban 2018.

18 Da je Ante Pavelić bio svjestan da pisana riječ u novinama dopire do širokoga kruga čitatelja pa je važno da bude u duhu ustaške jezične politike, svjedoči činjenica da je novinare nazivao apostolima čistoće hrvatskoga jezika. Usp. Labus 2011.

19 Primjerice, 16. travnja 1942. (god. V, br. 222) novim je pravopisom zapisano tek nekoliko riječi, npr.: družtvima, priedlog, obćine, obćina, činovničtvo, obćinar, ciena.

20 Naravno, to ne znači da su svi primjeri uvijek bili zapisani novim morfonološkim pravopisom, o čemu će više riječi biti u nastavku integralnoga teksta.

21 Usp. bilješku 6. 


\section{Odraz jata}

U Hrvatskom je jedinstvu od rujna 1942. godine zabilježeno sustavno bilježenje dvoslova ie za dugi odraz jata i je za kratki odraz:

zviezda, cviećem, vrieme, cieli, vriedni, liečnika, liepe, primietile, riedkih, tiekom, tiesne, kolievkom, sliepoga, prieki, sieno, bieg, ocieni, bies, smiešiš, trieznom, odniela, vienac, poviest, mlieko, diete, ciena, cienjen, upotriebiti, plien, sriedu, viesti, propovied, poviestnom, namienjena, viećnik, razumievanja, pridonieli, piesak, pobolievaju, siečnja, sliepoga, uviek, Osieka, Sriemu, Varaždinbrieg; 22 vjerom, pobjedom, bjesnoća, Cvjetnica, ponedjeljak, cjenik, uvjetom, namještenje, djecu, posjede, vjekove, povjestničar, vječna, mjesto, posjeći, pjevač, vjerodostojna, ovdje, namještenici, medvjed.

Ustaška je vlast tako nastavila tradiciju zagrebačke filološke školenaslijeđenu iz 19. stoljeća, prije pojave hrvatskih vukovaca. ${ }^{23}$

$\mathrm{U}$ ranijim su brojevima uz primjere s ostvarajem ie u dugom slogu potvrđeni i oni s ostvarajem ije, primjerice: zahtijeva, bijesni, vijeće, poslije, smiješno, dijete, lijepo, propovijed, svijeta, vrijeme, nijesu, tijelo, tijesno, uslijed. Čestotnost je primjera s odrazom ije opadala svakim novim brojem. Valja napomenuti da su oba ostvaraja $u$ istim riječima potvrđena $u$ istim brojevima novina između travnja i rujna 1942. godine (npr. niesu i nijesu, sniega i snijega, biela i bijela, diete i dijete), ali i u istom tekstu (npr. riečima i riječima, obaviest i obavijest). Pojedina su kolebanja i odstupanja od norme zabilježena i nakon listopada 1942. godine. Primjer poslije sustavno se kroz sva analizirana godišta zapisuje ostvarajem ije. Izdvojimo i primjere u kojima je umjesto kratkoga ostvaraja jata je zapisan dug ostvaraj ie: sviestni, riešavani, zasiedanje, dviesta. Držimo da je razlog takvih potvrda neznanje ili omaška novinara. Neznanju se mogu pripisati i primjeri: pukovnie (G mn.), nacie ( $\mathrm{G} \mathrm{mn}$.), uvjerljivie, čiega (umjesto: pukovnije, nacije, uvjerljivije, čijega) u kojima ije nije dvoglasnik nego trofonemski niz.

U Provedbenoj naredbi stoji da »iza r ne dolazi prema ie kratko je, nego samo e; vrieme - vremena, brieg - bregovi; priek - preči. Ali ipak ostaje je u nekim slučajevima, kao što su: crjepovi, pogrješka, strjelica, vrjednoća (Samardžija 2008:150). Jednako pravilo, s većim brojem primjera, zapi-

22 Potvrđen je i zapis Varaždin-brieg.

23 Predstavnici su zagrebačke filološke škole u početku smatrali da jat valja pisati kao rogato e (̌̌). Polovicom je 19. stoljeća izgovor jata normiran kao ie u dugom slo$\mathrm{gu}$, je u kratkom slogu. Od trećeg izdanja Veberove gramatike Slovnica hrvatska za srednja učilišta (1876) jat se bilježi kao ie u dugom slogu, a je u kratkom slogu. O toj temi v. npr. Tafra 1993; Ham 1998; Ham 2006; Pranjković 2010; Morić-Mohorovičić 2014; Pranjković 2015. 
suju i Klaić (1942) te Cipra-Klaić (1944). Pojedini primjeri u analiziranom korpusu odstupaju od navedenoga pravila. Iako prevladavaju primjeri $u$ kojima za tzv. pokrivenim r slijedi e (preči, vremena, prenositi), dvostrukosti su potvrđene i nakon izdavanja Provedbene naredbe te nakon Klaićeva pravopisnog priručnika (1942): ždrebeta i ždrjebeta (umjesto propisanog oblika ždrebeta); pogreška i pogrješka (umjesto propisanog oblika pogrješka), ali nikada $\mathrm{u}$ istom tekstu. Odstupanje je od pravila zabilježeno i u riječima criepova, strielica u kojima bi, prema tadašnjoj normi, iza pokrivenoga $\mathrm{r}$ valjalo pisati $j e .^{24}$

\section{Jednačenje suglasnika po zvučnosti i mjestu tvorbe}

Nebilježenje je jednačenja po zvučnosti i mjestu tvorbe kao bitnih odrednica morfonološkoga pravopisa ustaška vlast tek najavila u Provedbenoj naredbi, ${ }^{25}$ a sama su pravila jasnije određena u Klaićevu (1942) te Cipra-Klaićevu priručniku (1944). S obzirom na to da je Hrvatsko jedinstvo na novi morfonološki pravopis prešlo u rujnu 1942. godine, u ranijim je brojevima potvrđeno mnoštvo primjera zapisanih prema dominantno fonološkom pravopisnom načelu. ${ }^{26}$ Tako primjerice u svibnju možemo pročitati: potpuno, uloške, općina, opskrbe, ispunjen, iskorištavanju, istraživanja; bešćutan, iščezla, a u lipnju: teškim, poštenjem, društvo, radništvo, iskrvave, raspršenim; obrambene, uščuvati. Broj se primjera u kojima su bilježena jednačenja smanjivao svakim novim brojem, da bi se od jeseni 1942. godine sveo na nevelik broj iznimaka.

Nebilježenje jednačenja po zvučnosti potvrđeno je u sljedećim primjerima:

- $\mathrm{u}$ imenica ispred sufiksa -(a)k: poredka, napredka, dolazka;

- $\mathrm{u}$ imenica ispred sufiksa -(a)c: lažca;

- u imenica ispred sufiksa -ba: svjedočba, glasba, promičba, brojitbom, ženitba, plovitba, selitba;

- u imenica ispred sufiksa -bina: otačbina;

- $\mathrm{u}$ imenica ispred sufiksa -ština: potrebštinama;

- u imenica ispred sufiksa ispred -kinja: robkinja, služkinja;

- u imenica ispred sufiksa -tvo: množtvo, družtvo;

24 Navedene su iznimke zabilježene u Provedbenoj naredbi te u Klaićevu (1942) i Cipra-Klaićevu (1944) pravopisnom priručniku.

25 Usp. Samardžija 2008:151-152.

26 Usp. bilješku 9. 
- $\mathrm{u}$ imenica ispred sufiksa -ka: tordka, Šlezke;

- u osobnih imena: Vladko, Božko;

- $\mathrm{u}$ imenica s prefiksom nad-: nadpisi;

- u pridjeva ispred sufiksa -(a)k: težka, sladko, riedko, mrzka, drzka, $d r z k i$;

- u pridjeva ispred sufiksa -ski/-ki: francuzki, englezki, parižki, geoložki, paleontoložki, mužki, bioložkom, stratežki, ideoložkoj, vitežkim;

- u pridjeva ispred sufiksa -čiji: drugčiji;

- u pridjeva ispred prefiksa bez-: bezsmrtnim, bezsavjestnih, bezkrajno, bezplatno, bezsmislene;

- $\mathrm{u}$ izvedenica s prefiksom iz-: izpjevao, izkazuje, iztičući, izpravama, izpit, izpitnog, izkusnog, izpupčenja, iztovar, izpunjen, izpoljuje, izkaznica, izkoriste, izpunjala, izpalio, iztakao, izkrcavanjem, izcrpljen, izčisti, izkonsku, izsječak, izključivo, iztjerani, izkazane, izseljenicima, iztrunu, izcrpe, izkorišćuje, iztrebljenju, iztrgli, izcrpljena, izkrenost, izprva, izhod, iztaknuvši, izživljavala, izčekuje, izpriča, izpekao, izsušenoj, izpijali;

- $\mathrm{u}$ izvedenica s prefiksom ob-: obći, obćina, obćinstva, obstanak, uobće, obseg, obširnije, obskrbiti, neobhodno, obtužujući, obstojao, obkolile, izobćuje;

- u izvedenica s prefiksom od-: odkup, odputovalo, odkupljuj, odtisnuo, odkazao, odpuštaju, odkrio, odtjerali, odputi;

- $\mathrm{u}$ izvedenica s prefiksom pod-: podpuna, podhvatima, podpuno, podkrovlje;

- $\mathrm{u}$ izvedenica s prefiksom raz-: razpravljati, raztjerati, razkomada$t i$, raztati, razpravama, razčistila, razštrkanih, raztepenog, razsvjeta, razplodne, razpačavanjem, raztočiti, razkralj, razpršen, razkužitelji, razpoloženja, raztruje, razčlanjenje, raztočiše, razkrinkala, raztužena, razkrstio, razpolaganju;

- $\mathrm{u}$ izvedenica s prefiksom uz-: uzpio, uzkotračna, uzkliknuo, uztrajno, uzprkos, uzčuvanje, uzkolebati, uzpostavu, uztvrdila, Uzkrs, uzkrsni;

- u glagola ispred sufiksa -ti: prevezti;

- u glagola ispred sufiksa -sti: zebsti;

- u glagola ispred sufiksa -čati: otežčati;

- u nekim složenicama: petdeset. 
Da pisanje po novim pravilima nije bilo tako jednostavno, svjedoče iznimke potvrđene i nakon rujna 1942. godine. Važno je napomenuti da je $\mathrm{u}$ to vrijeme tiskano i Klaićevo Koriensko pisanje, ${ }^{27}$ koje propisuje kada (ne) bilježiti jednačenja po zvučnosti i mjestu tvorbe. ${ }^{28}$ Unatoč tome, $u$ analiziranim je brojevima potvrđen nevelik broj primjera u kojima je jednačenje po zvučnosti, protivno pravilima, bilježeno, npr.: rietko, ljupka, društvovno, glazba (umjesto propisanih: riedko, ljubka, družtvovno, glasba). U potvrđenom primjeru siromačtvo, koji i Klaić (1942) izrijekom navodi, ${ }^{29}$ valjalo je pisati: siromaštvo. ${ }^{30}$

Iako je već Provedbena naredba izvedenice »u kojima dolazi priedlog s« (Provedbena naredba, prema Samardžija 2008:152) svrstala u odstupanje od korienskoga pravopisa, $\mathrm{u}$ analiziranu su korpusu potvrđene brojne iznimke od tadašnje norme, npr. sborovanje, sbor, sbir, sbivaju, sbogom (umjesto propisanih: zborovanje, zbor, zbir, zbivaju, zbogom). U primjerima se uzpomena, uzpjeh, izti, izkra, izstina, iztok, modka, družtvo, plidka (umjesto: uspomena, uspjeh, isti, iskra, istina, istok, motka, društvo, plitka) po analogiji pogrešno ukida opreka po zvučnosti. Nesigurnost je potvrđena i u sintagmi jezična promičba, ${ }^{31}$ kao bitne odrednice ustaške jezične politike. Uz jezična promičba, potvrđeni su i primjeri (jezična) promidžba, promiđba, promićba te oblik promićbenom.

$\mathrm{U}$ analiziranom je korpusu jednačenje po mjestu tvorbe potvrđeno $\mathrm{u}$ primjerima u kojima $s$ i $z$ ispred $\check{c}, c, a, l j, n j, \check{s}, \check{z}$ prelaze u $\check{s}$ i $\check{z}$, primjerice Siščanin, pažljiv, lišće, grožđe, gošća, ščepati, vožnja. Takvo pisanje, koje je »ostalo dosta sačuvano « (Klaić 1942:33) u pismu, normirano je i u Klaićevu Korienskom pisanju ${ }^{32}$ te dvije godine kasnije u Cipra-Klaićevu Hrvatskom korienskom pravopisu. ${ }^{33}$ Jednačenje sustavno izostaje u primjerima s prefiksima bez-, iz-, raz-, uz-, u kojima izostaje i jednačenje po zvučnosti te ispadanje suglasnika: bezčastan, izčisti, izčekuje, uzčuvanje, razčlanjenje, razčistila, razštrkanih, razširen, čime se sustavno prati pravopisna norma ustaške vla-

27 Knjižica je izišla »na početku školske godine« (Samardžija 2008: 56), početkom rujna 1942.

28 Usp. Klaić 1942:30-34, 37-55.

29 »/.../Razlikuj: rieči kao monaštvo, siromaštvo, ustaštvo, u kojima je u osnovi h odnosno š (monah, siromah, ustaša)« (Klaić 1942:40).

30 U analiziranom korpusu oblik siromaštvo nije potvrđen.

31 Jezična promičba (njem. Sprachwerbung) sintagma je nastala u vrijeme nacizma. Označavala je kultiviranje hrvatskoga jezika i širenje znanja o njemu. O jezičnoj promičbi usp. npr. Samardžija 2008.

32 Usp. Klaić 1942:33.

33 Usp. Cipra-Klaić 1944:42-44. 
sti. ${ }^{34}$ Jedina je potvrđena iznimka primjer uščuvan (god. VIII, br. 61, 20. siječnja 1945. godine). Da su novinari dobro poznavali pravila morfonološkoga pravopisa koje normira Klaić (1942), a potvrđuju Cipra-Klaić (1944), svjedoče i sljedeće dvije skupine primjera u kojima nije zabilježeno jednačenje po mjestu tvorbe. ${ }^{35} \mathrm{U}$ prvoj skupini promjena se ne bilježi ispred sufiksa -tvo (nastao od -stvo). U tim se slučajevima u osnovi piše glas č koji je postankom od $k$ ili $c$ : seljačtvo, junačtvo, radničtvo, zajedničtvo, predstavničtou, namjesničtvo, zločinačtou, mračnjačtva, četničtou, tajničtvo. U drugoj skupini nije zabilježena promjena $n \mathrm{u} m$ ispred $b$ i $p$ : prehranbenih, obranbena, stanbena, nastanba, činbenici, jedanput.

\section{Ispadanje suglasnika}

Sustavnija su pravila o ispadanju suglasnika na granicama morfema u Nezavisnoj Državi Hrvatskoj potvrđena u Klaićevu (1942) i Cipra-Klaićevu priručniku (1944). ${ }^{36}$ Ipak, velik je broj primjera u kojima promjena izostaje potvrđen i prije negoli ih je Klaićev priručnik normirao, primjerice: desetci, dužnostnik, bolestnik, namjestnik, dodatci, Mletčanin, bolestnica, odčepiti. Nakon rujna 1942. čuvanje je suglasnika na granicama morfema u analiziranim brojevima sustavno provođeno, primjerice:

otca, otčev, ovlastnikom, poviestnu, poviestnom, Mletčanin, gostba, srdce, častnik, ustmen, gostba, predstavničtvo, gubitci, izvrstnim, učestnik.

Otklon od tadašnje norme potvrđen je u malobrojnim primjerima u kojima je valjalo provesti promjenu: središtnjica, godištnji, srdčan ${ }^{37}$ (umjesto propisanih: središnjica, godišnji, srčan). ${ }^{38}$ Koliko su se novinari nastojali držati korijenskoga pravopisa, svjedoči mnoštvo zapisa, npr. svetčanom, pjestnik, godištnji, sebitčan, glastnik, pistmen, pistmenost, zapovjednikčtvo, željezdnica, okolištni, ukostnica, nebestki. Takvi su korijenski primjeri rezultat

34 Usp. »Ovakvo je izjednačavanje promienjeno samo u slučajevima, kada je s njime spojeno izjednačavanje po zvučnosti i ispadanje suglasnika, izazvano izjednačavanjem po govornom ustroju, u tvorbi rieči s nastavkom -čić i s predmetcima bez-, iz-, raz-, uz- /.../.« (Klaić 1942:33).

"Kod složenih rieči ne mienja se suglasnik, kojim se završava prvi dio složenice. Prema tome se ravnaju: a) složenice s priedlogom: /.../ bez /.../iz /.../, /raz /.../, iz /.../.« (Klaić 1944:40).

35 Usp. Klaić 1942:33-34; Cipra-Klaić 1944:41.

36 O ispadanju suglasnika u Provedbenoj naredbi stoji tek jedno pravilo: »/.../ Izuzimaju se rieči, gdje je pisanje dd neobhodno potrebno za razumievanje, na pr. preddvorje, poddialekt, poddnevnik« (Samardžija 2008:152).

37 Pridjev u značenju 'junačan' valjalo je pisati srčan, a pridjev je srdčan označavao 'ono što pripada srcu'. Usp. Klaić 1942:121; Cipra-Klaić: 1944: 367, 368.

38 Usp. Klaić 1942; Cipra-Klaić 1944. 
pisanja »po osjećaju « (Samardžija 2008:47), nastali analogijom bez poznavanja korijena riječi.

\section{Zaključak}

Oživljavanje morfonološkoga pravopisnog načela ustaška je vlast opravdavala s povratkom hrvatskoj pravopisnoj tradiciji. ${ }^{39}$ Pravopis je pritom imao simboličko značenje - označavao je priklanjanje političkoj struji. Riječju - za tadašnji režim ili protiv njega. Odlučno, ali brzopleto uspostavljanje nove pravopisne norme označilo je prekid sa stečenim pravopisnim navikama širokoga kruga ljudi. Hrvatsko jedinstvo bilo je glasilo ustaške vlasti. Usprkos strogom jezičnom nadzoru i poslušničkom žaru šire javnosti, iz analize je vidljivo da je $u$ javnoj komunikaciji postojala nesigurnost $u$ prihvaćanju novih pravopisnih rješenja. Naizgled jednostavna pravila morfonološkoga pisanja imala su brojne iznimke jer, unatoč najavi, ${ }^{40}$ dosljedno morfonološki pravopis nije moguć. ${ }^{41} \mathrm{Iz}$ analiziranih primjera možemo zaključiti da je velik broj kršenja tadašnje pravopisne norme potvrđen upravo u primjerima u kojima se odstupa od proklamiranoga pravopisnog načela, primjerice: pogreška, siromaštvo, sborovanje, sbor, središtnjica, godištnji. Nepoznavanje tadašnje pravopisne norme s jedne strane te pogrešna shvaćanja morfonološkoga pravopisa kao dosljednoga s druge potakli su na pogrešne analogije, primjerice uvjerljivie, čiega, uzpomena, uzpjeh, izti, izkra, izstina, iztok, modka, družtvo, plidka, pjestnik, godištnji, sebitčan, pistmenost, zapovjednikčtvo, okolištni, ukostnica. Najmanje je otklona od norme potvrđeno zbog utjecaja prijašnje Broz-Boranićeve pravopisne norme, npr. rietko, ljupka, društvovno, uščuvan. Iz navedenoga možemo zaključiti da je izravan, snažan i nepopustljiv politički diktat totalitarnoga režima nagnao govornike hrvatskoga jezika na to da prihvate novi morfonološki pravopis, bez poznavanja njegove norme, što je rezultiralo brojnim odstupanjima od tadašnje pravopisne norme u pisanoj komunikaciji.

39 Valja naglasiti da je dominantno morfonološki pravopis bio oznakom tek jednoga dijela hrvatske jezične povijesti - hrvatskih iliraca te zagrebačke filološke škole. O toj temi usp. npr. Badurina 2006, Badurina 2015.

40 »Na hrvatskom se jeziku ima pisati po korienskom, a ne po zvučnom pravopisu« (Zakonska odredba, prema Samardžija 2008:139).

41 »Nema pravopisa zasnovana isključivo na jednom od tih dvaju načela (fonološkoga ili morfonološkoga op. B. M. M.); svakim se pravopisom uspostavlja specifičan omjer oboga« (Badurina 2015:426). 


\section{Izvori}

Hrvatsko jedinstvo, god. IV, br. 184, 26. travnja 1941.

Hrvatsko jedinstvo, god. IV, broj 186, 10. svibnja 1941.

Hrvatsko jedinstvo, god. IV, broj 193, 26. lipnja 1941.

Hrvatsko jedinstvo, god. IV, broj 200, 14. kolovoza 1941.

Hrvatsko jedinstvo, god. IV, broj 209, 16. listopada 1941.

Hrvatsko jedinstvo, god. V, broj 220, 1. siječnja 1942.

Hrvatsko jedinstvo, god. V, broj 222, 16. travnja 1942.

Hrvatsko jedinstvo, god. V, broj 223, 23. travnja 1942.

Hrvatsko jedinstvo, god. V, broj 224, 30. travnja 1942.

Hrvatsko jedinstvo, god. V, broj 225, 7. svibnja 1942.

Hrvatsko jedinstvo, god. V, broj 227, 21. svibnja 1942.

Hrvatsko jedinstvo, god. V, broj 229, 4. lipnja 1942.

Hrvatsko jedinstvo, god. V, broj 231, 18. lipnja 1942.

Hrvatsko jedinstvo, god. V, broj 233, 2. srpnja 1942.

Hrvatsko jedinstvo, god. V, broj 236, 22. srpnja 1942.

Hrvatsko jedinstvo, god V, broj 238, 6. kolovoza 1942.

Hrvatsko jedinstvo, god. V, broj 241, 27. kolovoza 1942.

Hrvatsko jedinstvo, god. I, broj 1, 10. rujna 1942.

Hrvatsko jedinstvo, god. I, broj 2, 17. rujna 1942.

Hrvatsko jedinstvo, god. I, br. 3, 24. rujna 1942.

Hrvatsko jedinstvo, god. I, br. 4, 1. listopada 1942.

Hrvatsko jedinstvo, god. I, br. 6, 15. listopada 1942.

Hrvatsko jedinstvo, god. I, br. 10, 12. studenoga 1942.

Hrvatsko jedinstvo, god. I, br. 16, 25. prosinca 1942.

Hrvatsko jedinstvo, god. II, br. 4, 28. siječnja 1943.

Hrvatsko jedinstvo, god. II, br. 8, 25. veljače 1943.

Hrvatsko jedinstvo, god. II, br. 9, 4. ožujka 1943.

Hrvatsko jedinstvo, god. VI, br. 13, 1. travnja 1943.

Hrvatsko jedinstvo, god. VI, br. 15, 15. travnja 1943.

Hrvatsko jedinstvo, god. VI, br. 16, 22. travnja 1943.

Hrvatsko jedinstvo, god. VII, br. 8, 8. siječnja 1944.

Hrvatsko jedinstvo, god. VII, br. 13, 12. veljače 1944.

Hrvatsko jedinstvo, god. VII, br. 18, 11. ožujka 1944.

Hrvatsko jedinstvo, god. VII, br. 30, 3. lipnja 1944.

Hrvatsko jedinstvo, god. VII, br. 41, 19. kolovoza 1944.

Hrvatsko jedinstvo, god. VII, br. 47, 30. rujna 1944. 
Hrvatsko jedinstvo, god. VII, br. 54, 18. studenoga 1944.

Hrvatsko jedinstvo, god. VII, br. 59, 25. prosinca 1944.

Hrvatsko jedinstvo, god. VIII, br. 61, 20. siječnja 1945.

Hrvatsko jedinstvo, god. VIII, br. 64, 10. veljače 1945.

Hrvatsko jedinstvo, god. VIII, br. 67, 3. ožujka 1945.

\section{Literatura}

Badurina, Lada. 2006. Hrvatska pravopisna norma u 20. stoljeću. Ur. Samardžija, Marko; Ivo Pranjković. Hrvatski jezik u XX. stoljeću. Zagreb: Matica hrvatska, 145-158.

Bičanić, Ante i dr. ${ }^{2} 2013$. Pregled povijesti, gramatike i pravopisa hrvatskoga jezika. Zagreb: Croatica.

Badurina, Lada. 2010. Standardizacijski procesi u 20. stoljeću. Ur. Mićanović, Krešimir. Povijest hrvatskoga jezika - Književne prakse sedamdesetih. Zagreb: Zagrebačka slavistička škola, 69-101.

Badurina, Lada. 2015. Hrvatski slovopis i pravopis u 19. stoljeću. Ur. Lisac, Josip; Ivo Pranjković, Marko Samardžija. Povijest hrvatskoga jezika, 4. knjiga: 19. stoljeće. Zagreb: Croatica, 403-429.

Badurina, Lada. 2018. Hrvatski pravopisi i pravopisna norma u 20. stoljeću. Ur. Bičanić, Ante; Ivo Pranjković, Marko Samardžija. Povijest hrvatskoga jezika, 5. knjiga: 20. stoljeće - proi dio. Zagreb: Croatica, 153-190.

Baraban, Borko. 2018. Jezično kultiviranje hrvatskoga jezika i jezično savjetništvo u 20. stoljeću, Ur. Bičanić, Ante; Ivo Pranjković; Marko Samardžija. Povijest hrvatskoga jezika, 5. knjiga: 20. stoljeće - proi dio. Zagreb: Croatica, 441-478.

Brozović, Dalibor. 1985. Jezična i pravopisna previranja u Hrvatskoj na prijelazu iz 19. u 20. stoljeće. Jezik, 33-1, 1-15.

Bućin, Rajka. 2001. Prilog poznavanju institucija: zakonski okvir rada velikih župa NDH. Arh. vjesnik, 44, 209-225.

Cipra, Franjo; Adolf Bratoljub Klaić. 1944. Hrvatski pravopis. Zagreb: Izdanje Nakladnog odjela Hrvatske državne tiskare.

Ham, Sanda. 1998. Jezik zagrebačke filološke škole. Osijek: Matica hrvatska.

Ham, Sanda. 2006. Povijest hrvatskih gramatika. Zagreb: Nakladni zavod Globus.

Huzjan, Vladimir. 2012. Varaždin u zadnjim mjesecima Kraljevine Jugoslavije i prvim Nezavisne Države Hrvatske. Radovi Zavoda za znanstveni rad Varaždin, 23, 363-399.

Jelić-Butić, Fikreta. ${ }^{2} 1987$. Ustaše i Nezavisna Država Hrvatska. Zagreb: Školska knjiga. 
Jonjić, Tomislav. 2011. Pitanje državnosti Nezavisne Države Hrvatske. Časopis za suvremenu povijest, 43-3, 667-698.

Klaić, Adolf Bratoljub. 1942. Koriensko pisanje. Zagreb: Union Grafičko-nakladni zavod d.d.

Krstić, Kruno. 9. studenoga 1941. Zakon i red u jeziku. Pitanje pravopisa. Hrvatski narod, 3-267, 12.

Jonke, Ljudevit. 1971. Hrvatski književni jezik 19. i 20. stoljeća. Zagreb: Matica hrvatska.

Labus, Alan. 2011. Politika i novine u Nezavisnoj Državi Hrvatskoj. Zagreb: Plejada.

Morić-Mohorovičić, Borana. 2014. Gramatičar Dragutin Antun Parčić. Doktorska disertacija. Rijeka: Filozofski fakultet.

Pranjković, Ivo. 2010. Hrvatski jezik u 19. stoljeću. Ur. Mićanović, Krešimir. Zbornik radova 38. seminara Zagrebačke slavističke škole. Zagreb: FF Press, 49-68.

Pranjković, Ivo. 2015. Filološke škole i hrvatski standardni jezik u drugoj polovici 19. stoljeća. Ur. Lisac, Josip; Ivo Pranjković; Marko Samardžija. Povijest hrvatskoga jezika, 4. knjiga: 19. stoljeće. Zagreb: Croatica, 77-112.

Rišner, Vlasta. 2006. Hrvatsko jezično savjetništvo u 20. stoljeću. Ur. Samardžija, Marko; Ivo Pranjković. Hrvatski jezik u XX. stoljeću. Zagreb: Matica hrvatska, 367-394.

Samardžija, Marko. 1993. Hrvatski jezik u Nezavisnoj Državi Hrvatskoj. Zagreb: Hrvatska sveučilišna naklada.

Samardžija, Marko. 2002. Nekoć i nedavno. Odabrane teme iz leksikologije i novije povijesti hrvatskoga standardnog jezika. Biblioteka Dometi, knj. 139. Rijeka: Izdavački centar Rijeka.

Samardžija, Marko. 2004. Iz triju stoljeća hrvatskoga standardnog jezika. Zagreb: Hrvatska sveučilišna naklada.

Samardžija, Marko. 2008. Hrvatski jezik, pravopis i jezična politika u NDH. Zagreb: Hrvatska sveučilišna naklada.

Samardžija, Marko. 2014. Pogovor uz pretisak Ivan Broz. Hrvatski pravopis (1892). Zagreb: Institut za hrvatski jezik i jezikoslovlje, 145-194.

Škiljan, Dubravko. 1988. Jezična politika. Zagreb: Naprijed.

Tafra, Branka. 1993. Gramatika u Hrvata i Vjekoslav Babukić. Zagreb: Matica hrvatska. 


\title{
Orthographic Norm in The Independant State of Croatia (on the example of the newspaper Hrvatsko jedinstvo)
}

\begin{abstract}
The paper analyzes orthographic norm in Hrvatsko jedinstvo during the period of The Independent State of Croatia. The normative features of the new morphonological orthographic norm have been listed in Ministarska naredba o hrvatskom pravopisu (1941), Zakonska odredba o hrvatskom jeziku, o njegovoj čistoći i o pravopisu (1941), Provedbena naredba $k$ zakonskoj odredbi o hrvatskom jeziku, o njegovoj čistoći i pravopisu (1942) and clarified in two orthography books: Koriensko pisanje (1942) written by Adolf Bratoljub Klaić and Hrvatski pravopis (1944) written by Franjo Cipra and Adolf Bratoljub Klaić. The analysis will also determine when did Hrvatsko jedinstvo start to use dominant morphonological orthographic norm.

Ključne riječi: Hrvatsko jedinstvo, novine, NDH, pravopis, 20. stoljeće

Keywords: Hrvatsko jedinstvo, newspaper, The Independent State of Croatia, orthographic norm, 20th century
\end{abstract}

